\title{
OBITUARIES
}

\section{Sir Gilbert Walker, C.S.I., F.R.S.}

SIR GILbERT WALKER died on November 4, some four months after his ninetieth birthday. For half a century his has been a prominent name in meteorological circles, and in recent years one was apt to forget that he had been elected a Fellow of the Royal Society for original work in dynamics and electromagnetism before ever he turned his thoughts to meteorology.

Walker went up to Trinity College, Cambridge, from St. Paul's School with a mathematical scholarship. He fully confirmed his early promise on graduating as the Senior Wrangler in the Mathematical Tripos of 1889 , an achievement that was followed in due course by election to a fellowship of Trinity and then to a lectureship, both of which he held until going to India. From 1892 onwards he published a series of papers on the theory of electromagnetism, for one of which he was awarded an Adams Prize in 1900. In the same period he was showing a keen interest in dynamical problems, with papers on such subjects as the motion of elongated projectiles, dynamical tops and boomerangs, in which his interests were not wholly theoretical, for he became expert as designer and thrower of boomerangs, and indeed was known in the Cambridge of those days as 'Boomerang Walker'. It is a matter for some regret that his article on "Spiel und Sport" in the great "Encyklopädie der Mathematischer Wissenschaften" was never well known to his own compatriots.

Walker went to India in 1903 to succeed Sir John Eliot as director-general of observatories. The great Indian famine of 1899-1900 was still very much in people's minds and, as it were, challenged Walker to attempt to solve the very complex and difficult problem of forecasting the monsoon rainfall. The physical causes that produce the fluctuations from year to year defied and still defy detection. Walker decided to apply the statistical methods of correlation and soon made the subject of seasonal 'foreshadowing' by these methods peculiarly his own. His investigations, beginning with the search for relationships between previous weather over different parts of the globe and the Indian monsoon rainfall, developed into an examination of the interrelations of world-wide variations of weather, contemporary and consecutive. His papers are a mine of statistical information on world weather, interspersed with concise, critical and acute comment. Of the more important generalizations that emerged, there was one that he called the Southern Oscillation, which may be described as a tendency for air to disperse from the Pacific area at the same time as air accumulates in and around the Indian Ocean. The monsoon plays a part in the Southern Oscillation, out of the elements of which he evolved a formula for 'foreshadowing' monsoon rainfall, which has continued in use in India with but little amendment. Walker would not claim to have solved the monsoon problem, but he pointed a way, and the value of these papers can scarcely be overestimated.

Living in the Simla hills, Walker was fascinated by the soaring flight of birds, at first as a hobby, then as a study on which he wrote several papers, including the article in the "Encyclopædia Britannice" on animal flight.

After retiring from India in 1924, Walker succeeded Sir Napier Shaw as professor of meteorology at the Imperial College of Science and Technology, London. One of the subjects to which he turned his own and his pupils' attention was the cellular structure of an unstable fluid. In striking laboratory experiments they obtained a variety of cellular forms-polygons, transverse and longitudinal vortices-by varying the rate of shear in the fluid, and they were able to show that this physical process explained the mode of formation of a wide variety of cloud forms.

Walker lived in Cambridge from 1934 until after the Second World War, officially retired but continuing to write papers on meteorological subjects. During the War he acted, in effect, as an honorary consultant on problems of long-range forecasting.

Walker was a man of wide interests, a highly proficient skater and climber in his younger days, always very fond of music, happy to spend a day out of doors sketching in water colour, ever eminently reasonable, liberal minded and very friendly. In all his posts he demonstrated his great intellectual capacity and served with distinction, deservedly reaping many honours during his long life.

\section{Charles Normand}

\section{Mr. Stephen Butterworth, O.B.E. .}

STEPHEN BUTTERWORTH died on October 28 at the age of seventy-three at his home in Cowes, Isle of Wight, having retired from the Admiralty scientific staff in 1945.

After being educated at the University of Manchester, Butterworth was for eleven years a lecturer in physics at the Manchester Municipal College of Technology. Afterwards he worked for a few years on electrical standards at the National Physical Laboratory before joining the Admiralty Research Laboratory in 1921, where he remained for twentyfour years until his retirement.

Butterworth was a first-rate mathematician who possessed the rare ability to apply his mathematics successfully to a wide variety of practical problems. Before his Admiralty period he was mainly concerned with electrical investigations such as the theoretical determination of standards of inductance and accurate methods of measurement. This work, unlike much of what he did later, was fully published in the scientific Press, and his theoretical formulæ for inductances and the high-frequency resistance of coils have been extensively quoted and used.

His achievements with the Admiralty are too numerous to mention in detail, but the following indicate the diversity of his activities. In his early days he studied the possibilities of ship navigation by the use of a 'leader cable'; and, by solving the complicated electromagnetic field surrounding a submarine cable carrying alternating current, he was able to provide a complete theoretical background for all subsequent design work. He concerned himself with underwater weapons and made valuable contributions to our understanding of the stability of torpedoes 
which led to significant improvements in design. At another period he gave his attention to underwater explosion phenomena and among other things predicted the multiple oscillations of the explosion gas bubble, an effect that was observed experimentally many years later. In the early part of the Second World War he was much involved with the problem of the magnetic mine and made big contributions to the successful degaussing of our ships.

Butterworth possessed the ability to apply his mathematics to problems which at first sight appeared unlikely to admit of mathematical solution. He was, however, able to make progress in many cases by introducing judicious approximations to the physical conditions. Naturally, much depends on knowing the right approximations to make, and in this respect Butterworth invariably displayed an unerring understanding of the physical realities of the situation. $\mathrm{H}_{\Theta}$ also showed ingenuity in devising experiments both to test his theories and to make progress with problems too complex for mathematical treatment. Naval science is often concerned with large-scale effects, where systematic and extensive experimentation is very difficult. In such cases he would aim at devising a model which could be studied exhaustively in the laboratory. He was able to show, for example, that the complicated details of magnetization of a ship's structure under the combined influence of its degaussing coils and the magnetic field of the Earth could be accurately reproduced using an appropriately scaled steel model of the ship. This made possible an enormous saving of effort when degaussing specifications had to be worked out for a variety of ships during the Second World War. In the same way, he was able to study the trajectories and the effects on entering the water of underwater projectiles by means of small models in a laboratory tank, thus reducing the need for difficult and expensive full-scale experiments at sea. In this case the technique which he developed at Teddington many years ago has been followed by other laboratories ever since.

For security reasons it was impossible for Butterworth to publish much of his work, and on this account his general recognition in the scientific world has been much less than it would otherwise have been.

Although one of the most outstanding scientists in the Admiralty's service, Butterworth was a very quiet and unassuming man. His expert advice was sought on all sides, and he was always ready to give it. His colleagues throughout the Admiralty scientific service had deep respect for him, and those young men fortunate enough to work under his direction held him almost in veneration. H. F. Wrilis

\section{NEWS and VIEWS}

The Queen's University, Belfast :

Prof. Michael Grant, C.B.E.

Prof. Michael Grant, who holds the chair of humanity in the University of Edinburgh, has been elected president and vice-chancellor of The Queen's University, Belfast. He will succeed Sir Eric Ashby (who takes up residence as master of Clare College, Cambridge, next July) in August 1959. Prof. Grant brings a wealth of experience to his new office. He was educated at Harrow and Trinity College, Cam. bridge. In 1938 he was elected into a Fellowship at Trinity. During the War he was seconded from the Army as British Council representative in Turkey and he later became deputy director of the European Division of the British Council. In 1948 he was appointed professor of humanity in the University of Edinburgh, and during 1956-58 he had leave of absence from his chair to serve as first vice-chancellor of the University of Khartoum. He filled the office of vice-chancellor at Khartoum with distinction through a period of great political and constitutional unrest. Prof. Grant goes to The Queen's University at a time when it is developing rapidly. He will have the double responsibility of maintaining the University's international status and at the same time preserving the University's close ties with its region. He has high qualifications for this double responsibility, and it is a cause of great satisfaction that university education in Ulster will be under such experienced leadership.

Department of Leather Industries, University of Leeds : Prof. D. Burton

Ir has been announced that Prof. D. Burton is to retire in September 1959 from the chair of leather industries in the University of Leeds, which he has held since 1951. Since 1955 he has also been director of the Procter International Research Laboratory, where he was at one time the first research assistant. During his tenure of office there has been a considerable expansion of the activities of his Department. The courses have been revised and the research facilities greatly extended; an electron microscope has been installed and put to good use; the experi. mental tannery has been modernized and re-equipped; a laboratory for microscopy and bacteriology has been opened; and the Atkin-Thompson postgraduate research laboratory added. Among the topics studied has been the nature and material of the Dead Sea Scrolls. Prof. Burton is widely known and respected in the leather industry as well as in academic circles, and a large number of friends will wish him well in his retirement.

\section{Prof. A. G. Ward}

Mr. A. G. WARD has been appointed to succeed Prof. Burton. After obtaining first-class honours in physics at Cambridge and working, for a time, in the Department of Colloid Science in that University, Mr. Ward was lecturer in physics and mathematics at the Technical College at Stoke-on-Trent, until the Second World War, when he worked with the Armament Research Department. During 1946-49 he was in charge of research on rheology at the Building Research Station, after which he became the first director of the British Gelatine and Glue Research Association. Apart from his duties as director, Mr. Ward has made notable advances in our knowledge of the properties of gelatine. His authoritative article (with P. R. Saunders) in the recently published second volume of F. R. Eirich's "Rheology : Theory and Applications" is of outstanding merit. Though Mr. Ward's interests cover a wide field of colloid science, and his little book on colloids, published in 1945, has been much praised, he is perhaps 